\title{
Vitamin D nutritional status in preterm infants and response to supplementation
}

\author{
Roberta A. McCarthy ${ }^{1 *}$, Malachi J. McKenna ${ }^{2,3}$, Oyinkansola Oyefeso ${ }^{1}$, Ogenna Uduma ${ }^{1}$, \\ Barbara F. Murray ${ }^{3}$, Jennifer J. Brady ${ }^{3}$, Mark T. Kilbane ${ }^{3}$, John F. Murphy ${ }^{1}$, Anne Twomey ${ }^{1}$, \\ Colm P. O' Donnell ${ }^{1}$, Nuala P. Murphy ${ }^{4}$ and Eleanor J. Molloy ${ }^{1,4,5,6}$ \\ ${ }^{1}$ Department of Neonatology, National Maternity Hospital, Holles Street, Dublin 2, Republic of Ireland \\ ${ }^{2}$ Department of Endocrinology, St. Vincent's University Hospital, Dublin 4, Republic of Ireland \\ ${ }^{3}$ Metabolism Laboratory, St Vincent's University Hospital, Dublin 4, Republic of Ireland \\ ${ }^{4}$ Department of Endocrinology, Children's University Hospital, Dublin 1, Republic of Ireland \\ ${ }^{5}$ School of Medicine and Medical Science, University College Dublin, Dublin, Republic of Ireland \\ ${ }^{6}$ Royal College of Surgeons of Ireland, Dublin 2, Republic of Ireland
}

(Submitted 29 March 2012 - Final revision received 10 August 2012 - Accepted 17 September 2012 - First published online 5 November 2012)

\begin{abstract}
Little is known about vitamin D status in preterm infants and their response to supplementation. To investigate this, we assessed serum 25-hydroxyvitamin D (25OHD) levels using RIA in a consecutive sample of stable preterm very low birth weight (VLBW) infants (born $\leq 32$ weeks gestation or birth weight $\leq 1.5 \mathrm{~kg}$ ), and we explored associated factors. Serum 25OHD level was first assessed once infants were tolerating feeds $(n$ 274). If this first $250 H D$ level was below $50 \mathrm{nmol} / \mathrm{l}(20 \mathrm{ng} / \mathrm{ml})$, which is the level associated with covering requirements in terms of skeletal health in the majority, then we recommended prolonged augmented vitamin D intake ( $\geq 10 \mu \mathrm{g}(400 \mathrm{IU})$ daily) from a combination of fortified feeds and vitamin supplements and follow-up re-assessment at approximately 6 weeks corrected age ( $n$ 148). The first assessment, conducted at a median for chronological age of 18 (interquartile range (IQR) $11-28$ ) $\mathrm{d}$, found that $78 \%$ had serum $25 \mathrm{OHD}$ levels below $50 \mathrm{nmol} / 1$. Multivariable analysis demonstrated that the determinants of serum 25OHD levels were duration of vitamin D supplementation and gestational age at birth $\left(r^{2} 0 \cdot 215 ; P<0 \cdot 001\right)$. At follow-up, after a median of 104 (IQR 78-127) d, 87\% achieved levels $\geq 50 \mathrm{nmol} / 1$ and $8 \%$ had levels $>125 \mathrm{nmol} / 1$, a level associated with potential risk of harm. We conclude that low $25 \mathrm{OHD}$ levels are an issue for preterm VLBW infants, warranting early nutritional intervention. In infants with serum $25 \mathrm{OHD}$ levels $<50 \mathrm{nmol} / \mathrm{l}$, a vitamin D intake of $\geq 10 \mu \mathrm{g}$ (400 IU) daily achieves target levels in the majority; however, further work is needed to determine the exact dose to safely meet target levels without overcorrection.
\end{abstract}

Key words: Preterm infants: Vitamin D nutrition: Vitamin D supplementation

Recognition of vitamin D deficiency early in life is important due to its effect on skeletal and non-skeletal health ${ }^{(1,2)}$. Vitamin $\mathrm{D}$ is an essential micronutrient for good bone health, with low 25-hydroxyvitamin D (25OHD) levels linked to rickets in children, a resurgence of which has been reported across many countries ${ }^{(3)}$. As vitamin $\mathrm{D}$ is important for the innate immune system, it may also have implications in neonatal sepsis ${ }^{(4)}$. Furthermore, vitamin D deficiency in infancy may be a risk factor for extra-skeletal chronic disease later in life such as autoimmune diseases like type 1 diabetes mellitus and atopy, although evidence to date is inconclusive ${ }^{(5)}$. Preterm infants are at particular risk of vitamin D deficiency because they are dependent on maternal vitamin D status in utero (which is in turn dependent on both sunlight exposure and oral vitamin $\mathrm{D}$ intake) and on nutritional intake after birth for vitamin D supply ${ }^{(1,2)}$. However, there is controversy about the adequate daily dose, duration and type of vitamin D supplementation.

The Institute of Medicine (IOM) recently revised the dietary reference intakes for the USA and Canada ${ }^{(5,6)}$. Using a risk assessment model, they specified the estimated average requirement that meets the average need for vitamin $\mathrm{D}$ and the recommended daily allowance that meets the need of $97.5 \%$ of the population. Furthermore, accepting 25OHD as

Abbreviations: 25OHD, 25-hydroxyvitamin D; ALP, alkaline phosphatase; ESPGHAN, European Society for Paediatric Gastroenterology, Hepatology, and Nutrition; IOM, Institute of Medicine; IQR, interquartile range; VLBW, very low birth weight.

*Corresponding author: R. A. McCarthy, fax +35316614623, email rmccarthy@nmh.ie 
a biomarker of exposure but not as a biomarker of effect, they specified that a $25 \mathrm{OHD}$ level of $40 \mathrm{nmol} / \mathrm{l}$ corresponded to the estimated average requirement and that a level of $50 \mathrm{nmol} / 1$ corresponded to the recommended daily allowance. So, $25 \mathrm{OHD}$ is both a measure of the adequacy of supply and of risk for disease, but is not in itself a clinical outcome ${ }^{(7)}$.

For infants from birth to 1 year, the IOM does not specify an estimated average requirement or a recommended daily allowance for vitamin D due to lack of studies ${ }^{(5,8)}$. Instead, an adequate intake that is likely to meet the needs of most has been specified at $10 \mu \mathrm{g}$ (400 IU) daily ${ }^{(1,5)}$. There are even fewer data available to guide about nutritional intake in preterm infants. The IOM suggested that vitamin D intakes ranging from $4 \mu \mathrm{g}$ (160 IU) to $10 \mu \mathrm{g}$ (400 IU) daily seem adequate $^{(5)}$, while the European Society for Paediatric Gastroenterology, Hepatology, and Nutrition (ESPGHAN) advised a higher vitamin D intake of $20-25 \mu \mathrm{g}$ (800-1000 IU) daily from a combination of feeds and supplements, and set a higher threshold level for serum $25 \mathrm{OHD}$ at $80 \mathrm{nmol} / \mathrm{l}^{(9)}$

As the adequacy of the above-mentioned recommendations in routine clinical practice in preterm infants has not been evaluated, we aimed to do so and to assess the response to long-term augmented vitamin $\mathrm{D}$ nutritional intake of $\geq 10 \mu \mathrm{g}$ (400 IU) daily in those with a first serum 25OHD level $<50 \mathrm{nmol} / \mathrm{l}$.

\section{Methods \\ Patient population}

A consecutive sample of stable preterm very low birth weight (VLBW) (gestation $\leq 32$ weeks or birth weight $\leq 1.5 \mathrm{~kg}$ ) infants, admitted to the Neonatal Unit over 26 months (June 2008-July 2010), was audited. This is a tertiary referral university centre, with approximately 10000 deliveries and 160 VLBW admissions annually, of which approximately $50 \%$ are transfers from other hospitals. All convalescentstable VLBW infants were eligible for inclusion, but infants were excluded if they were transferred or died before meeting this criterion. Serum 25OHD level was first assessed once each infant was tolerating feeds. Demographic data gathered included gestational age, birth weight, sex, ethnicity, season of birth and chronological age at time of first serum 25OHD assessment. This was a prospective audit of routine clinical practice in our unit and did not involve either additional blood tests or alteration in the management of the infants concerned.

\section{Vitamin D nutritional strategy}

Vitamin D intake was augmented from birth according to our clinical practice guidelines, as outlined below, in order to achieve and maintain serum $25 \mathrm{OHD}$ levels $\geq 50 \mathrm{nmol} / \mathrm{l}$. At first, infants received vitamin $\mathrm{D}_{2}$ from intravenous fat-soluble vitamin supplements (Vitlipid N, Fresenius Kabi), prescribed while receiving parenteral nutrition at a dose that provided $4 \mu \mathrm{g}(160 \mathrm{IU}) / \mathrm{kg}$ body weight daily (Table 1$)$. Infants then advanced to enteral feeds, which were expressed breast

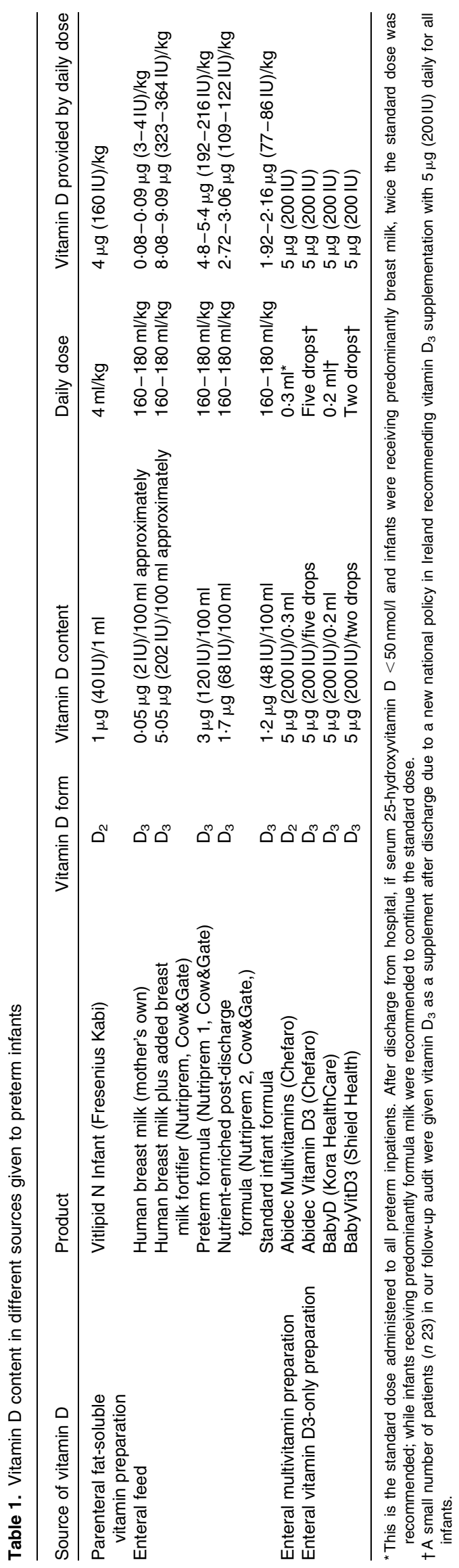


Table 2. Categorical variables of the total group and divided according to first vitamin $\mathrm{D}$ status

\begin{tabular}{|c|c|c|c|c|c|}
\hline \multirow[b]{2}{*}{ Variable } & \multirow[b]{2}{*}{$\begin{array}{l}\text { Total group } \\
\quad(n 274)\end{array}$} & \multicolumn{3}{|c|}{ Serum 25OHD (nmol/l) } & \multirow[b]{2}{*}{$P$} \\
\hline & & $\begin{array}{l}<30 \\
(n 38)\end{array}$ & $\begin{array}{c}30-49 \cdot 9 \\
(n 177)\end{array}$ & $\begin{array}{l}\geq 50 \\
(n 59)\end{array}$ & \\
\hline Ethnicity (\%) & & & & & 0.216 \\
\hline Caucasian & 89 & 84 & 89 & 95 & \\
\hline Non-Caucasian & 11 & 16 & 11 & 5 & \\
\hline $\operatorname{Sex}(\%)$ & & & & & 0.302 \\
\hline Boys & 43 & 32 & 45 & 44 & \\
\hline Girls & 57 & 68 & 55 & 56 & \\
\hline $\begin{array}{l}\text { Birth weight } \geq 9 \text { th } \\
\text { centile }(\%)\end{array}$ & & & & & 0.564 \\
\hline Yes & 75 & 68 & 75 & 78 & \\
\hline No & 25 & 32 & 25 & 22 & \\
\hline $\begin{array}{l}\text { Supplement } \\
\text { started before } \\
\text { assessment (\%) }\end{array}$ & & & & & $0.003^{*}$ \\
\hline Yes & 38 & 13 & 41 & 44 & \\
\hline No & 62 & 87 & 59 & 56 & \\
\hline
\end{tabular}

25OHD, 25-hydroxyvitamin D.

*Value was significantly different between the three groups.

milk (vitamin $\left.\mathrm{D}_{3} 0.05 \mu \mathrm{g}(2 \mathrm{IU}) / 100 \mathrm{ml}\right)^{(2)}$ plus breast milk fortifier (vitamin $D_{3} 5.05 \mu \mathrm{g}(202 \mathrm{IU}) / 100 \mathrm{ml}$ ), preterm formula milk (vitamin $\left.\mathrm{D}_{3} 3 \mu \mathrm{g}(120 \mathrm{IU}) / 100 \mathrm{ml}\right)$ or a combination of both. Finally, after establishment of full enteral feeds, vitamin supplements were commenced that provided an additional $5 \mu \mathrm{g}$ (200 IU) vitamin $\mathrm{D}_{2}$ daily using Abidec Multivitamins (Chefaro ${ }^{\circledR}$ ). We aimed to ensure a vitamin $\mathrm{D}$ intake of $\geq 10 \mu \mathrm{g}$ (400 IU) daily, consisting of $\geq 5 \mu \mathrm{g}$ (200 IU) vitamin $\mathrm{D}_{3}$ from enteral feeds and $5 \mu \mathrm{g}$ (200 IU) vitamin $\mathrm{D}_{2}$ from supplements.

\section{Audit of response to prolonged augmented vitamin D} intake

In those infants with a first $25 \mathrm{OHD}$ level $<50 \mathrm{nmol} / \mathrm{l}$, we aimed to audit their vitamin D status again at about 6 weeks corrected age (calculated by subtracting the number of weeks born before 40 weeks of gestation from the chronological age $\left.{ }^{(10)}\right)$. For these infants, we aimed to continue a daily vitamin D intake of $\geq 10 \mu \mathrm{g}$ (400 IU) after discharge, in keeping with American Academy of Pediatrics' recommendations $^{(1)}$. After discharge, breast milk fortifier was no longer added to breast milk, and formula milk was changed to a nutrient-enriched post-discharge formula (vitamin $\mathrm{D}_{3} 1.7 \mu \mathrm{g}$ (68 IU) $/ 100 \mathrm{ml}$ ); later, this formula was changed to standard formula milk (vitamin $\mathrm{D}_{3} 1 \cdot 2 \mu \mathrm{g}$ (48 IU)/100 ml) depending on the infant's growth. In order to continue a daily vitamin D intake of $\geq 10 \mu \mathrm{g}$ ( $400 \mathrm{IU}$ ), for infants who were breastfed or partially breastfed, we recommended supplementation with $10 \mu \mathrm{g}$ ( $400 \mathrm{IU}$ ) vitamin $\mathrm{D}_{2}$ daily, but for those predominately taking formula milk, we advised supplementation with $5 \mu \mathrm{g}(200 \mathrm{IU})$ vitamin $\mathrm{D}_{2}$ daily. Near the end of our audit, the supplemental form of vitamin $\mathrm{D}$ was switched from vitamin $D_{2}$ to $D_{3}$, as a consequence of a national policy of infant vitamin $\mathrm{D}_{3}$ supplementation in Ireland (Table 1).

\section{Laboratory methods}

Serum total alkaline phosphatase (ALP), total corrected Ca and $\mathrm{P}$ were measured using standard automated techniques. Serum total ALP was missing in eleven patients, and both serum-corrected $\mathrm{Ca}$ and serum $\mathrm{P}$ were missing in one patient. Serum 25OHD levels were measured by competitive RIA (Immunodiagnostic Systems Limited), as previously described $^{(11)}$. We participate in the Vitamin D External Quality Assessment Scheme ${ }^{(12)}$.

\section{Statistics}

Descriptive statistics are presented as medians and interquartile ranges (IQR), means and standard deviations or numbers and percentages. The total group was divided into three sub-groups based on IOM thresholds for 25OHD (Tables 2 and 3). Differences between mean values for continuous variables were tested by one-way ANOVA, with Bonferroni

Table 3. Continuous variables of the total group and divided according to first vitamin $\mathrm{D}$ status $\dagger$ (Mean values and standard deviations)

\begin{tabular}{|c|c|c|c|c|c|c|c|c|c|}
\hline \multirow[b]{3}{*}{ Variable } & & & \multicolumn{6}{|c|}{ Serum $25 \mathrm{OHD}(\mathrm{nmol} / \mathrm{l})$} & \multirow[b]{3}{*}{$P$} \\
\hline & \multicolumn{2}{|c|}{ Total group (n 274) } & \multicolumn{2}{|c|}{$<30(n 38)$} & \multicolumn{2}{|c|}{$30-49.9(n 177)$} & \multicolumn{2}{|c|}{$\geq 50(n 59)$} & \\
\hline & Mean & SD & Mean & SD & Mean & SD & Mean & SD & \\
\hline Gestational age at birth (weeks) & $29 \cdot 3$ & 2.5 & 30.0 & $2 \cdot 3$ & $29 \cdot 2$ & $2 \cdot 5$ & $29 \cdot 0$ & $2 \cdot 7$ & 0.158 \\
\hline Birth weight $(\mathrm{kg})$ & 1.23 & 0.36 & 1.30 & 0.33 & 1.22 & 0.36 & $1 \cdot 22$ & 0.38 & 0.457 \\
\hline $\begin{array}{l}\text { Chronological age at time } \\
\text { of assessment (d) }\end{array}$ & $22 \cdot 0$ & $16 \cdot 9$ & $14 \cdot 2$ & $11 \cdot 1$ & $22 \cdot 1$ & $13 \cdot 8$ & $26 \cdot 7$ & $25 \cdot 1$ & $0.002^{*}$ \\
\hline $\mathrm{Ca}(\mathrm{mmol} / \mathrm{l})$ & 2.63 & 0.15 & 2.58 & 0.16 & 2.62 & 0.13 & $2 \cdot 68$ & 0.12 & $<0.001^{*}$ \\
\hline $\mathrm{P}(\mathrm{mmol} / \mathrm{l})$ & 1.97 & 0.40 & 1.77 & 0.41 & 1.98 & 0.39 & 2.06 & 0.39 & $<0.002^{*}$ \\
\hline Total ALP & & & & & & & & & 0.925 \\
\hline IU/I & 1027 & 449 & 1001 & 441 & 1033 & 433 & 1027 & 449 & \\
\hline$\mu \mathrm{g} / \mathrm{l}$ & $25 \cdot 68$ & 11.23 & 25.03 & 11.03 & $25 \cdot 83$ & $10 \cdot 83$ & 25.68 & 11.23 & \\
\hline
\end{tabular}

25OHD, 25-hydroxyvitamin D; ALP, alkaline phosphatase.

${ }^{*}$ Mean values were significantly different between the three groups.

†Total number $=274$, except for serum total ALP ( $n$ 263), serum Ca $(n$ 273) and serum $\mathrm{P}$ ( $n$ 273). Laboratory serum reference values: Ca, 1.8-2.7 mmol/l; P, $1.62-2.52 \mathrm{mmol} / \mathrm{l}$; total ALP $3.65-25 \mu \mathrm{g}(146-1000 \mathrm{lU}) / \mathrm{l}$. 
correction for post hoc comparisons. Differences between categorical variables were tested by $\chi^{2}$ test. Bivariate associations were assessed by Pearson's correlation coefficients or Spearman's $\rho$ coefficients. We conducted a forward multiple linear regression analysis in order to identify independent associations of individual factors in determining serum 25OHD levels at first assessment. We selected independent variables for the regression model if bivariate analysis was $P<0.20$ and if there was no evidence of multicollinearity, as judged by correlation coefficient $P<0 \cdot 8^{(13)}$. Results with $P<0.05$ were considered statistically significant. Statistical analysis was performed using SPSS for Windows version 20.0 (SPSS, Inc.)

\section{Results}

\section{Descriptive statistics}

We evaluated 372 preterm VLBW infants who were admitted to the Neonatal Unit during the audit period; 274 infants were entered into the clinical audit and had blood drawn for serum 25OHD assessment and the remaining ninety-eight infants were discharged, transferred to another hospital or died prior to assessment (Fig. 1). Comparing those studied and those not, there was no statistical difference with respect to gestational age at birth, birth weight, prevalence of infants with birth weight below the 9th centile and sex.

The mean for gestational age at birth was 29.3 (SD 2.5) weeks and for birth weight was 1.23 (SD 0.36) kg. There were 156 (57\%) male and 118 (43\%) female infants; 245 (89\%) were Caucasian and twenty-nine (11\%) non-Caucasian; and sixty-nine $(25 \%)$ had a birth weight $<9$ th centile (Tables 2 and 3). The median for chronological age at time of first serum 25OHD level assessment was 18 (IQR 11-28) d. Of the 274 infants who had a first assessment, 170 (62\%) were assessed prior to initiation of additional $5 \mu \mathrm{g}$ (200 IU) vitamin $\mathrm{D}_{2}$ supplements and 104 (38\%) were assessed afterwards. In the latter group, the median of duration of additional vitamin $\mathrm{D}$ supplementation prior to assessment of serum 25OHD level was 12 (IQR 5-20) d.

\section{Vitamin D status}

The median for first serum 25OHD was 39.4 (absolute range $20 \cdot 1-116 \cdot 0) \mathrm{nmol} / \mathrm{l}$. We interpreted the vitamin D status with

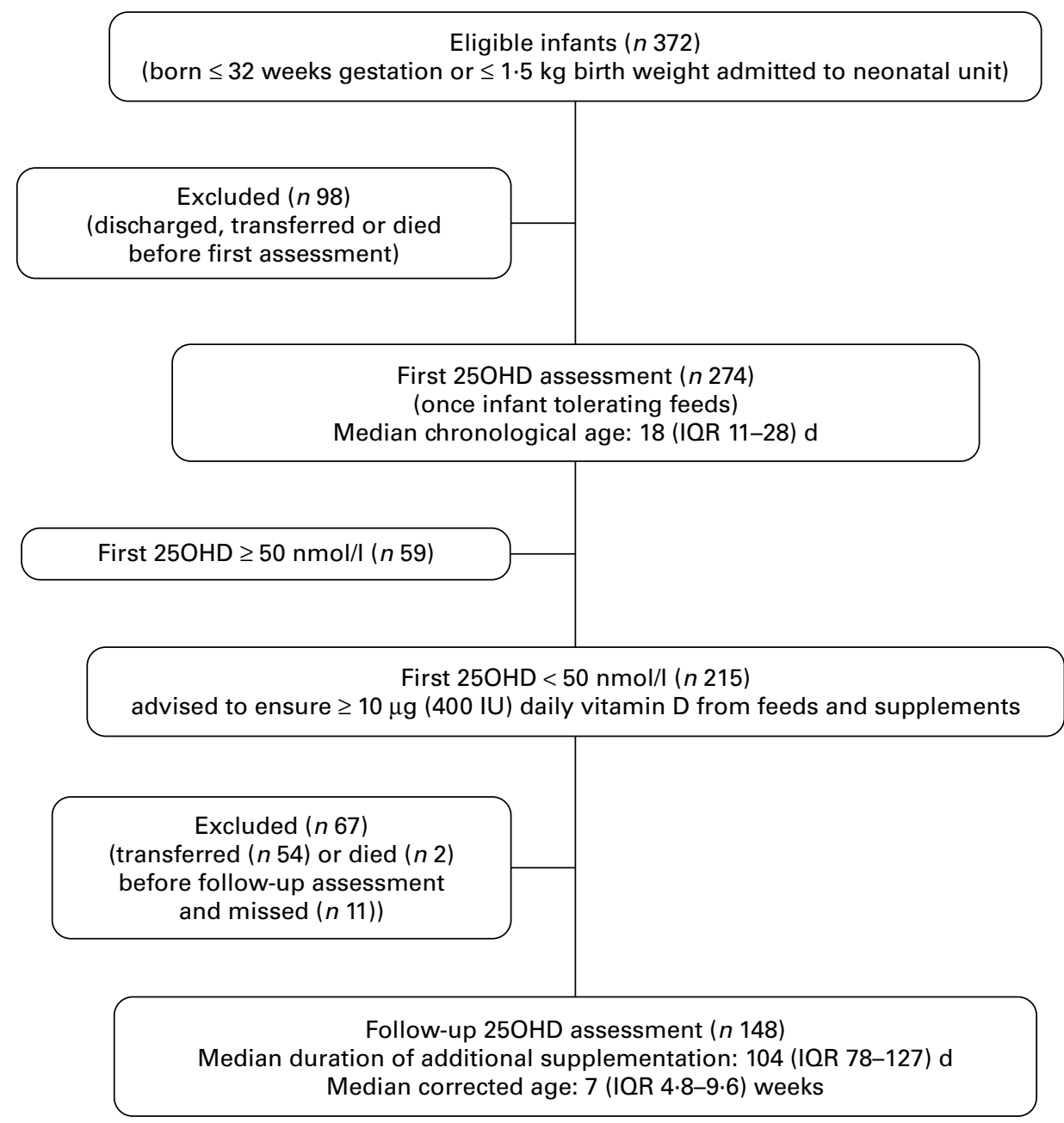

Fig. 1. Flow-chart outlining first and follow-up audit. 25OHD, 25-hydroxyvitamin $D$; IQR, interquartile range. 
respect to the IOM report that was published after completion of our first data collection. According to the IOM estimate of serum $25 \mathrm{OHD}$ status that corresponded to the IOM's specification on the distribution of vitamin $\mathrm{D}$ requirement ${ }^{(5)}$, the following prevalence figures were noted: thirty-eight (14\%) below the level associated with increased risk of rickets $(<30 \mathrm{nmol} / \mathrm{l}) ; 177(65 \%)$ within the IOM range of adequacy $(30-49.9 \mathrm{nmol} / 1)$; and fifty-nine (22\%) above the IOM target level that is associated with sufficiency in $97.5 \%$ of the population $^{(5,7)}(\geq 50 \mathrm{nmol} / \mathrm{l})$. In those assessed prior to receiving additional vitamin D supplementation ( $n$ 170), compared with those who had started additional supplementation at the time of assessment ( $n$ 104), the respective prevalence figures were as follows: serum $25 \mathrm{OHD}$ levels below $30 \mathrm{nmol} / 1$ (19 v. 5\%); between 30 and $49 \mathrm{nmol} / 1$ (61 v. 70\%); and $\geq 50 \mathrm{nmol} / 1(19$ v. $25 \%)(P=0.002)$.

\section{Relationship between vitamin D status and clinical measurements}

Higher first serum 25OHD levels were associated significantly with greater chronological age at the time of assessment $(P=0.002)$ and having started additional vitamin D supplementation at time of assessment $(P=0.003)$ (Tables 2 and 3). Serum $25 \mathrm{OHD}$ levels correlated in order of significance with the following variables: duration of vitamin $\mathrm{D}$ supplementation ( $r$ 0.456; $P<0.001)$; chronological age at the time of assessment $(r$ 0.368; $P<0.001)$; having started additional vitamin $D$ supplementation at the time of assessment $(\rho=0.245 ; P<0.001)$; and gestational age at birth ( $r-0.187 ; P=0.002)$; but not with ethnicity, sex, season of birth or birth weight. After adjusting for those who received additional vitamin D supplementation and the duration of administration prior to assessment, serum 25OHD levels still correlated with chronological age at the time of assessment ( $r$ 0.190; $P=0 \cdot 002$ ), indicating a positive relationship between duration of enteral feeding and vitamin $\mathrm{D}$ status irrespective of additional supplementation.

The multivariable analysis of first serum 25OHD levels included the following four independent variables that meet the selection criteria: gestational age at birth, chronological age at time of serum 25OHD assessment, having started additional supplementation at the time of assessment and duration of additional vitamin D supplementation prior to assessment. In the forward linear regression model, the predictors of serum 25OHD levels were duration of vitamin D supplementation prior to assessment and gestational age at birth (adjusted $r^{2} 0 \cdot 215 ; P<0 \cdot 001$ ).

\section{Relationship between vitamin D status and secondary indices of vitamin $D$ deficiency}

The relationship between first serum 25OHD levels and secondary indices was examined by correlation analysis. Following adjustment for chronological age at time of assessment, birth weight and gestational age at birth, serum 25OHD levels correlated negatively with serum total ALP $(r-0 \cdot 123$; $P=0.047)$ and positively with both serum Ca ( $r$ 0.226;
$P<0.001)$ and serum $\mathrm{P}(r 0 \cdot 263 ; P<0 \cdot 001)$. Serum $\mathrm{P}$ correlated with both serum $\mathrm{Ca}(r 0 \cdot 174 ; P=0.004)$ and with serum total ALP $(r-0.321 ; P<0.001)$; serum Ca correlated with serum total ALP $(r-0 \cdot 150 ; P=0 \cdot 015)$.

\section{Follow-up assessment in infants with first serum 25-hydroxyvitamin D levels $<50 \mathrm{nmol} / \mathrm{l}$}

First serum 25OHD levels were $<50 \mathrm{nmol} / 1$ in 215 infants, of which follow-up serum 25OHD level was assessed in 148 . Of the remaining sixty-seven infants, fifty-four had been transferred to other hospitals and results were not available, two had died and eleven missed testing. Comparing those assessed ( $n$ 148) with those not ( $n$ 67), there was no significant difference with respect to first serum 25OHD level, ethnicity or sex.

At the time of follow-up assessment, the median for duration of supplementation was 104 (IQR 78-127) d. The median for corrected age was 7.0 (IQR 4.8-9.6) weeks. Mean serum 25OHD levels increased significantly from $36.7(\mathrm{sD} 7 \cdot 2) \mathrm{nmol} / \mathrm{l}$ to $82.7 \quad(\mathrm{sD} 28.6) \mathrm{nmol} / \mathrm{l} \quad(t=19 \cdot 5$; $P<0.001$ ). The median increase in $25 \mathrm{OHD}$ was 44.3 (IQR $29 \cdot 2-63 \cdot 4) \mathrm{nmol} / \mathrm{l}$. Only four infants (3\%) had serum $25 \mathrm{OHD}$ levels $<30 \mathrm{nmol} / 1$, sixteen (11\%) were between 30 and $49.9 \mathrm{nmol} / 1$ and $128(87 \%)$ were $\geq 50 \mathrm{nmol} / \mathrm{l}$. We noted that twelve (8\%) infants achieved serum 25OHD levels that exceeded $125 \mathrm{nmol} / \mathrm{l}$ (Fig. 2). On post hoc analysis, we defined a poor response as failure to achieve serum 25OHD level $\geq 50 \mathrm{nmol} / 1$ coupled with an increment of $<10 \mathrm{nmol} / 1$; these criteria were met in fifteen of 148 infants (10\%). Of the fifteen infants, five had necrotising enterocolitis: one infant had stage III necrotising enterocolitis with a gastrointestinal perforation; four had stage I or II necrotising enterocolitis, not requiring surgical intervention; but all made a full recovery and tolerated feeds subsequently. Regarding the infant with the highest level $(187.9 \mathrm{nmol} / \mathrm{l})$ at follow-up assessment, this infant had a first serum $25 \mathrm{OHD}$ level of $43.6 \mathrm{nmol} / \mathrm{l}$. We contacted the parent and found that the infant was receiving a nutrientenriched formula (vitamin $\left.\mathrm{D}_{3} 1.7 \mu \mathrm{g}(68 \mathrm{IU}) / 100 \mathrm{ml}\right)$ and twice the recommended supplementation dose of vitamin D (10 $\mu \mathrm{g}$ (400 IU) vitamin $\mathrm{D}_{3}$ daily) at the time of follow-up assessment (after $114 \mathrm{~d}$ and at 7 weeks corrected age). This

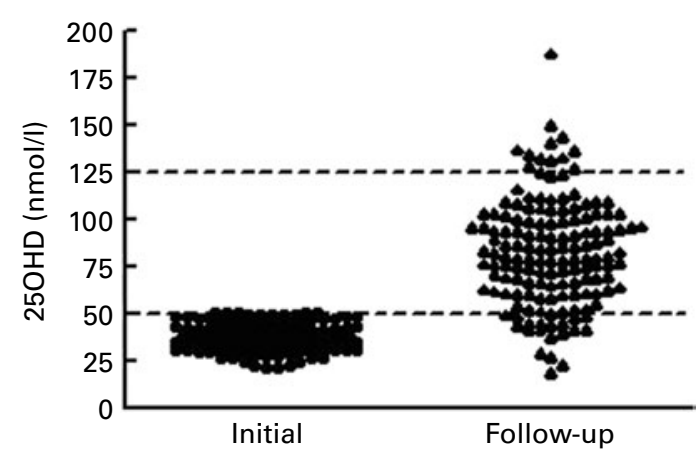

Fig. 2. Response to vitamin $D$ (intake $\geq 10 \mu \mathrm{g}(400 \mathrm{IU})$ ) in infants with first serum 25-hydroxyvitamin D (25OHD) below $50 \mathrm{nmol} / \mathrm{l}$ ( $n$ 148). Median duration of augmented vitamin D intake was 104 (interquartile range 78-127) d. Lines are drawn at the Institute of Medicine thresholds for recommended daily allowance at $50 \mathrm{nmol} / \mathrm{l}$ and for risk of toxicity at $125 \mathrm{nmol} / \mathrm{l}$. 
provided approximately $21 \cdot 25 \mu \mathrm{g}$ (850 IU) vitamin $\mathrm{D}_{3}$ daily ( $11.25 \mu \mathrm{g}$ (450 IU) daily from feeds plus $10 \mu \mathrm{g}$ (400 IU) daily from supplements). They were advised to cease supplementation and the nutrient-enriched formula, and to use instead standard formula milk $\left(1.2 \mu \mathrm{g}\right.$ (48 IU)/ $100 \mathrm{ml}$ vitamin $\left.\mathrm{D}_{3}\right)$. This reduced their intake to approximately $8 \mu \mathrm{g}$ (320 IU) vitamin $\mathrm{D}_{3}$ daily. After 10 weeks, at 17 weeks corrected age, the serum $25 \mathrm{OHD}$ level was $133.9 \mathrm{nmol} / \mathrm{l}$.

\section{Vitamin $D_{2}$ and $D_{3}$}

A small number of patients ( $n$ 23) in our follow-up audit were given vitamin $D_{3}$ rather than $D_{2}$ as a supplement after discharge, due to a new national policy in Ireland recommending supplementation with $5 \mu \mathrm{g}$ (200 IU) vitamin $\mathrm{D}_{3}$ daily for all infants from birth to 12 months. The mean serum 25OHD was $25 \%$ higher in those who received vitamin $\mathrm{D}_{3}$ compared with vitamin $\mathrm{D}_{2}(99.8$ (SD 37.8) v. 79.8 (sD 25.5) nmol/l; $P=0.023$ ).

We found a significant correlation between change in $25 \mathrm{OHD}$ and duration of supplementation after correction for form of vitamin D administered, sex, ethnicity and first 25OHD level $(r 0 \cdot 192 ; P=0 \cdot 021)$.

\section{Discussion}

The primacy of nutritional vitamin $\mathrm{D}$ intake over sunlight exposure in the prevention and correction of vitamin D deficiency is long established ${ }^{(14)}$, and is never as germane as in preterm infants. In this prospective audit of a representative sample of preterm or VLBW infants at a median of 3 weeks chronological age, $78 \%$ had a serum $250 \mathrm{HD}$ level below our target of $50 \mathrm{nmol} / \mathrm{l}$; however, only $14 \%$ had a level $<30 \mathrm{nmol} / \mathrm{l}$, reflecting the benefit of our policy of augmented vitamin $\mathrm{D}$ intake from birth. The principal determinant of serum 25OHD in the linear regression model was duration of additional vitamin D supplementation. The fact that first serum 25OHD correlated, weakly but significantly, with secondary indices, namely serum total ALP, Ca and P, may indicate that low serum 25OHD levels in these preterm infants already has had some adverse metabolic effect. In the present follow-up audit of infants with first serum 25OHD levels $<50 \mathrm{nmol} / \mathrm{l}$, after a median duration of additional supplementation of $104 \mathrm{~d}, 87 \%$ achieved levels $\geq 50 \mathrm{nmol} / 1$. The outcome may have been even better, because in $10 \%$ of infants we noted poor response based on our conservative criteria, suggesting either poor adherence or clinical conditions that affected response. Conversely, overcorrection was noted in $8 \%$, in that serum $25 \mathrm{OHD}$ exceeded $125 \mathrm{nmol} / 1$; this was identified by the IOM as potentially indicating risk of harm $^{(5)}$. On the basis of the present findings, we suggest that a vitamin D nutritional intake of $10 \mu \mathrm{g}$ (400 IU) daily, which is combined from feeds and supplements, achieves $25 \mathrm{OHD}$ levels $\geq 50 \mathrm{nmol} / 1$ in the majority. In the long term, once target levels have been achieved, a lower vitamin D intake for preterm infants may be adequate to maintain levels and obviate overcorrection, but strategies for compliance need to be addressed.
The possible reasons for the low serum 25OHD levels in our preterm infants once established on full feeds include: probable low vitamin D status at birth, because transplacental transfer of vitamin D mainly occurs in the last trimester and poor maternal vitamin $\mathrm{D}$ status at the time of birth in view of the close correlation between maternal serum 25OHD and cord 25OHD levels ${ }^{(2,15)}$. Pregnant women in Ireland and Great Britain frequently have poor vitamin D status ${ }^{(16,17)}$. Sub-optimal vitamin D status among Irish females of childbearing age and adolescents has also been reported similar to other northern European countries ${ }^{(18-23)}$. Ireland is at latitude $51-55^{\circ}$ North and there is no UV radiation of the appropriate wavelength above $42^{\circ}$ latitude in winter ${ }^{(24)}$. However, we did not find a relationship between season of birth and 25OHD levels. Poor vitamin D status is increasingly recognised in neonates born to mothers with either dark skin or concealing clothing ${ }^{(25)}$. However, we found no relationship between ethnicity and serum 25OHD. Of course, poor vitamin D status may be less relevant in preterm infants compared with term infants, because the former seem to rely on passive absorption of $\mathrm{Ca}$ and $\mathrm{P}$, with absorption being maximised by both the use of fortified breast milk and special preterm formulas; it is not clear what role vitamin D has at this stage with respect to Ca homeostasis, notwithstanding its purported role with respect to non-calcaemic issues ${ }^{(26,27)}$

Serum 25OHD is both a measure of vitamin D supply and an indicator of risk of disease. There has been a trend over the past two decades to define vitamin $\mathrm{D}$ deficiency in terms of the measured level, with thresholds steadily increasing from 25 up to $75 \mathrm{nmol} / \mathrm{l}^{(28)}$. The IOM demonstrated that serum 25OHD is not a health outcome; it is a measure of risk of a health outcome such as rickets. The IOM shunned the term vitamin D insufficiency, and it demonstrated that the risk of adverse skeletal outcomes is virtually absent when the serum $25 \mathrm{OHD}$ level exceeds $50 \mathrm{nmol} / \mathrm{l}^{(5)}$. The IOM specified an adequate intake of $10 \mu \mathrm{g}(400 \mathrm{IU}) / \mathrm{d}$ for infants from birth to 1 year, but noted that adequate intake, not being a recommended daily allowance, may be an overestimate of requirement. For preterm infants, the IOM did not make any specifications, but suggested that the need for vitamin D may be less in preterm infants, in view of their dependence on passive $\mathrm{Ca}$ absorption, and that any need was probably $4-10 \mu \mathrm{g}(160-400 \mathrm{IU}) / \mathrm{d}^{(5)}$. We found that vitamin D nutritional intakes of $\geq 10 \mu \mathrm{g}$ ( $400 \mathrm{IU}$ ) daily achieved serum 25 OHD levels of $\geq 50 \mathrm{nmol} / 1$ in $87 \%$.

The next consideration is to determine the upper safe serum $25 \mathrm{OHD}$ level, which some experts have set at $250 \mathrm{nmol} / \mathrm{l}^{(28)}$. The IOM expressed concern about levels above $125 \mathrm{nmol} / \mathrm{l}$, based on emerging evidence about risks that could not be defined in the usual terms of vitamin $\mathrm{D}$ toxicity ${ }^{(5)}$. While there are widely different views on the definition of both sufficiency and toxicity, the IOM report surpasses all other reports in scientific rigour and probity and is now the standard regarding vitamin $D$ requirement in all age groups ${ }^{(7,29)}$. In the present follow-up audit after a median duration of $104 \mathrm{~d}, 8 \%$ had levels $>125 \mathrm{nmol} / \mathrm{l}$ on an estimated nutritional intake of $\geq 10 \mu \mathrm{g}$ (400 IU) daily. We observed a very high serum 25 OHD level of $187.9 \mathrm{nmol} / 1$ in one infant, whose vitamin D 
intake at $21 \cdot 25 \mu \mathrm{g}(850 \mathrm{IU}) / \mathrm{d}$ exceeded our recommendation. This led us to question if the ESPGHAN recommendation of $20-25 \mu \mathrm{g}$ (800-1000 IU) daily for preterm infants may be excessive for routine clinical practice, and may seem to be justified for a limited duration. The evidence in term infants is that a daily dose of $6.25 \mu \mathrm{g}$ (250 IU) is safe and effective in achieving and maintaining adequate vitamin D status ${ }^{(30)}$.

The present audit has a number of limitations such as absence of data on maternal vitamin D status or maternal vitamin $\mathrm{D}$ intake. We did not formally evaluate a vitamin D dose response, in that infants were not tested prior to intervention and the exact intake for each infant was not measured, but rather we assessed the efficacy of the present protocol of vitamin D intake at achieving serum 25OHD levels $\geq 50 \mathrm{nmol} / 1$. We could not control for other potential determinants of vitamin D status such as intercurrent illness, progression through steps of augmenting vitamin D intake and adherence to advice regarding supplementation following discharge.

We must also acknowledge two issues with respect to the use of vitamin $\mathrm{D}_{2}$ compared with vitamin $\mathrm{D}_{3}$. The first is assay methodology; the present assay detected $75 \%$ of $25 \mathrm{OHD}_{2}$ and $100 \%$ of $25 \mathrm{OHD}_{3}$. The second is comparative effectiveness of similar doses of the two forms of vitamin D in raising total 25OHD levels. Two studies using physiological doses of vitamin D of $25 \mu \mathrm{g}$ (1000 IU) daily either show no difference in the rise in $25 \mathrm{OHD}$ levels ${ }^{(31)}$ or a $30 \%$ higher rise in serum 25OHD levels with vitamin $\mathrm{D}_{3}$ compared with vitamin $\mathrm{D}_{2}$, but without any difference in free serum $25 \mathrm{OHD}$ or serum parathyroid hormone levels ${ }^{(32,33)}$. Taking assay methodology and potential differences in serum 25OHD response to the administration of different forms of vitamin $\mathrm{D}$, and given that our infants received about $50 \%$ of their intake as vitamin $D_{2}$, it is likely that we have underestimated their serum 25OHD levels by about $10-15 \%$ at first assessment. In the follow-up audit, as some were taking the higher dose of vitamin $\mathrm{D}_{2}$ supplement, we may have underestimated levels by $20-30 \%$. We were able to confirm, in part, this underestimation, because a small number of patients ( $n$ 23) in the present follow-up audit were given vitamin $\mathrm{D}_{3}$ as a supplement after discharge due to a new national policy in Ireland recommending vitamin $\mathrm{D}_{3}$ supplementation with $5 \mu \mathrm{g}$ (200 IU) daily for all infants. The mean serum 25 OHD level was $25 \%$ higher in those who received supplements with vitamin $\mathrm{D}_{3}$ compared with vitamin $\mathrm{D}_{2}$.

\section{Conclusion}

We conclude that poor vitamin D status is an issue for preterm infants, warranting early nutritional intervention to prevent and correct. Nutritional intake of $10 \mu \mathrm{g}$ (400 IU) daily of vitamin D from all sources, starting as soon as possible from birth, achieves adequate vitamin D status. If serum 25OHD levels remain below $50 \mathrm{nmol} / 1$, then adherence should be questioned. In the long term, once adequate status has been achieved, a lower vitamin D intake may be sufficient to maintain levels and obviate overcorrection. A long-term randomised controlled trial comparing different intakes of vitamin D and evaluating multi-organ outcomes is warranted to determine the desired level of serum 25OHD for optimal health in preterm infants and the nutritional intake that is needed to safely achieve this level.

\section{Acknowledgements}

Authors' contributions were as follows: R. A. M. had responsibility for patient recruitment, data collection and contributed to protocol development, data analysis and writing the manuscript; M. J. M. had responsibility for data analysis and contributed to protocol development and writing the manuscript; O. O. and O. U. contributed to patient recruitment; B. F. M., J. J. B. and M. T. K. contributed to laboratory assessments; J. F. M., A. T., C. P. O. and N. P. M. contributed to protocol development; and E. J. M. had responsibility for protocol development and contributed to data analysis and writing the manuscript. We also wish to acknowledge the assistance of C. McCafferty and C. Murphy (Neonatal Clinical Nurse Specialists) and L. Phillips (Administration). This was an audit of our hospital policy of augmented vitamin D intake to a level of intake that was in keeping with present guidelines. As it was an audit of a routine clinical practice, we did not seek formal Ethics Committee approval. There was no conflict of interest that inappropriately influenced the action of any of the authors and the present research received no specific grant from any funding agency in the public, commercial or not-for-profit sectors.

\section{References}

1. Wagner CL \& Greer FR (2008) Prevention of rickets and vitamin D deficiency in infants, children, and adolescents. Pediatrics 122, 1142-1152.

2. Misra M, Pacaud D, Petryk A, et al. (2008) Vitamin D deficiency in children and its management: review of current knowledge and recommendations. Pediatrics 122, 398-417.

3. Welch TR, Bergstrom WH \& Tsang RC (2000) Vitamin Ddeficient rickets: the reemergence of a once-conquered disease. J Pediatr 137, 143-145.

4. Adams JS \& Hewison M (2010) Update in vitamin D. J Clin Endocrinol Metab 95, 471-478.

5. Institute of Medicine (2011) Dietary Reference Intakes for Calcium and Vitamin D. Washington, DC: National Academies Press.

6. Ross AC, Manson JE, Abrams SA, et al. (2011) The 2011 report on dietary reference intakes for calcium and vitamin $\mathrm{D}$ from the Institute of Medicine: what clinicians need to know. J Clin Endocrinol Metab 96, 53-58.

7. Aloia JF (2011) The 2011 report on dietary reference intake for vitamin D: where do we go from here? J Clin Endocrinol Metab 96, 2987-2996.

8. Institute of Medicine (1997) Dietary Reference Intakes for Calcium, Phosphorus, Magnesium, Vitamin D and Fluoride, pp. 250-287. Washington, DC: National Academies Press.

9. Agostoni C, Buonocore G, Carnielli VP, et al. (2010) Enteral nutrient supply for preterm infants: commentary from the European Society of Paediatric Gastroenterology, Hepatology and Nutrition Committee on Nutrition. J Pediatr Gastroenterol Nutr 50, 85-91.

10. Engle WA (2004) Age terminology during the perinatal period. Pediatrics 114, 1362-1364. 
11. Lonergan R, Kinsella K, Fitzpatrick P, et al. (2011) Multiple sclerosis prevalence in Ireland: relationship to vitamin D status and HLA genotype. I Neurol Neurosurg Psychiatry 82, 317-322.

12. Carter GD, Berry JL, Gunter E, et al. (2010) Proficiency testing of 25-hydroxyvitamin D (25-OHD) assays. J Steroid Biochem Mol Biol 121, 176-179.

13. Katz M (2006) Multivariable Analysis. A Practical Guide for Clinicians, 2nd ed. Cambridge: Cambridge University Press.

14. McKenna MJ (1992) Differences in vitamin D status between countries in young adults and the elderly. Am J Med 93, 69-77.

15. Viljakainen HT, Saarnio E, Hytinantti T, et al. (2010) Maternal vitamin $\mathrm{D}$ status determines bone variables in the newborn. J Clin Endocrinol Metab 95, 1749-1757.

16. O'Riordan MN, Kiely M, Higgins JR, et al. (2008) Prevalence of suboptimal vitamin D status during pregnancy. Ir Med J 101, 240, 242-243.

17. Holmes VA, Barnes MS, Alexander HD, et al. (2009) Vitamin $\mathrm{D}$ deficiency and insufficiency in pregnant women: a longitudinal study. Br J Nutr 102, 876-881.

18. Hill TR, Cotter AA, Mitchell S, et al. (2008) Vitamin D status and its determinants in adolescents from the Northern Ireland Young Hearts 2000 cohort. Br J Nutr 99, 1061-1067.

19. Hill TR, Flynn A, Kiely M, et al. (2006) Prevalence of suboptimal vitamin D status in young, adult and elderly Irish subjects. Ir Med J 99, 48-49.

20. Hill TR, O'Brien MM, Lamberg-Allardt C, et al. (2006) Vitamin D status of 51-75-year-old Irish women: its determinants and impact on biochemical indices of bone turnover. Public Health Nutr 9, 225-233.

21. McCarthy D, Collins A, O'Brien M, et al. (2006) Vitamin D intake and status in Irish elderly women and adolescent girls. Ir J Med Sci 175, 14-20.

22. Andersen R, Molgaard C, Skovgaard LT, et al. (2005) Teenage girls and elderly women living in northern Europe have low winter vitamin D status. Eur J Clin Nutr 59, 533-541.

23. O'Sullivan M, Nic Suibhne T, Cox G, et al. (2008) High prevalence of vitamin $\mathrm{D}$ insufficiency in healthy Irish adults. Ir J Med Sci 177, 131-134.
24. Webb AR, Kline L \& Holick MF (1988) Influence of season and latitude on the cutaneous synthesis of vitamin D3: exposure to winter sunlight in Boston and Edmonton will not promote vitamin D3 synthesis in human skin. $J$ Clin Endocrinol Metab 67, 373-378.

25. Dijkstra SH, van Beek A, Janssen JW, et al. (2007) High prevalence of vitamin $\mathrm{D}$ deficiency in newborn infants of high-risk mothers. Arch Dis Child 92, 750-753.

26. Bronner F, Salle BL, Putet G, et al. (1992) Net calcium absorption in premature infants: results of 103 metabolic balance studies. Am J Clin Nutr 56, 1037-1044.

27. Abrams SA (2011) Vitamin D deficiency and calcium absorption during infancy and childhood. In Vitamin D, 3nd ed., pp. 647-656 [D Fledman, JW Pike and JS Abrams, editors]. London: Elsevier Academic Press.

28. Holick MF, Binkley NC, Bischoff-Ferrari HA, et al. (2011) Evaluation, treatment, and prevention of vitamin D deficiency: an Endocrine Society clinical practice guideline. J Clin Endocrinol Metab 96, 1191-1930.

29. Rosen CJ, Abrams SA, Aloia JF, et al. (2012) IOM committee members respond to Endocrine Society vitamin D guideline. J Clin Endocrinol Metab 97, 1146-1152.

30. Siafarikas A, Piazena H, Feister U, et al. (2011) Randomised controlled trial analysing supplementation with 250 versus 500 units of vitamin D3, sun exposure and surrounding factors in breastfed infants. Arch Dis Child 96, 91-95.

31. Holick MF, Biancuzzo RM, Chen TC, et al. (2008) Vitamin D2 is as effective as vitamin D3 in maintaining circulating concentrations of 25-hydroxyvitamin D. J Clin Endocrinol Metab 93, 677-681.

32. Glendenning P, Chew GT, Seymour HM, et al. (2009) Serum 25-hydroxyvitamin D levels in vitamin D-insufficient hip fracture patients after supplementation with ergocalciferol and cholecalciferol. Bone 45, 870-875.

33. Chew G, Inderjeeth CA, Glendenning P, et al. (2010) Ergocalciferol and cholecalciferol induce comparable increases in vitamin $\mathrm{D}$ binding protein and free 25 -hydroxyvitamin D with no significant change in free 1,25-dihydroxyvitamin $\mathrm{D}$ in hip fracture patients. J Bone Miner Metab 25, Suppl. 1, S51. 